\title{
Endotracheal Intubation: The Minimum for ACLS Airway Management Training
}

\author{
Arthur J. Rubens, MD
}

The management of the airway and the delivery of oxygen are essential during respiratory and/or cardiopulmonary arrest. It should be a prime concern of emergency care providers, and must take precedence over everything but safety. ${ }^{1}$

Endotracheal intubation is the optimal method for securing and protecting the airway in the compromised patient. ${ }^{2-11}$ In 1975, the American Heart Association (AHA) developed specific standards for the instruction and subsequent certification of Advanced Cardiac Life Support (ACLS) airway management skills. ${ }^{2}$ The AHA instructs endotracheal (ET) intubation for airway management. Although there are several alternative methods and devices for maintaining a patient's airway besides ET intubation, the AHA incorporates the instruction of Esophageal Obturator Airway (EOA) or Esophageal Gastric Tube Airway (EGTA) as its alternative for airway management. 4,6,8,12,13

The initial perceived disadvantages with the instruction of ET intubation were difficulty in training paramedics and the possible complications associated with its use. ${ }^{8}$ Recent studies have indicated that the didactic training time for EOA/EGTA is 3.0 hours compared to 4.5 hours for endotracheal intubation, and that the clinical practice times were 1.0 and 2.5 hours respectively. ${ }^{5}$ Several studies have demonstrated that ET intubation can be performed in the prehospital setting and with complication rates no greater than EOA or EGTA insertion. ${ }^{14-16}$ Although the EOA/EGTA has been used in more than two million resuscitation attempts, ${ }^{8}$ several studies have shown a lack of effectiveness in prehospital ventilatory management following cardiac arrest. ${ }^{10,17}$ The EOA/EGTA is considered to be inferior to endotracheal intubation in field resuscitation of victims of cardiac arrest, ${ }^{9}$ and should be considered only as an alternative to endotracheal intubation, when ET intubation is not possible. ${ }^{11}$

In the past decade, much research and interest has been directed toward ways to reduce the occurrence of sudden death due to coronary heart disease. Much of this funding has gone toward the training and education of both laypersons and professionals in basic and advanced cardiac life support respectively. ${ }^{18}$ Some of this funding has gone to emergency medical systems for the development of a trained technician (Emergency Medical Technician-Defibrillation; EMT-D) to respond to the most frequent fatal arrthythmia of sudden death, ventricular fibrillation. ${ }^{18}$ In 1983, the Advanced Coronary Treatment (ACT) Foundation assembled its medical advisory board to review the available data from clinical experiences with the EMT-D. ${ }^{19}$ Much of the research demonstrated that the early use of the defibrillator by EMTs significantly improved survival from cardiac arrest. 20,21

Much like the upgrade of the EMT to EMT-D in certain communities, the instruction of ET intubation could be presented to the EMT. This training could replace the regular, periodic instruction for the EMT in EOA/EGTA insertion. The instruction and subsequent certification could be provided in a standarized ACLS course, with the EMT receiving a study packet and attending lectures and teaching stations on "airway adjuncts and intubation." More emphasis could be applied to the instruction of ET intubation, and the procedures of EOA/EGTA insertion could be phased out of the standarized ACLS course on airway adjuncts and intubation, and EMT training curriculum.

More research should be conducted into this concept of instructing solely ET intubation, and the subsequent impact that it would have on communities that now only have BLS capabilities and manage the compromised airway with EOA/EGTA insertion. Additionally, the idea of medical control over these new technicians would need to be explored.

There was a time, when it was felt that one could not train a prehospital care provider in the skills necessary to perform advanced life support. Today, the impact of this training is well known to both the public and medical community. The EMT/ paramedics have changed the course of prehospital and emergency care delivery. Their capabilities and skills are acknowledged and accepted. Nationally, many communities can not afford to support an ACLS system.

\section{Conclusion}

The EOA and EGTA have served their purpose for many years. Maybe the time has come to put aside these instruments. Many metropolitan communities already have done this. Perhaps, it is time that available resources were looked at to design ways that could improve training methods and more cost-effective use of EMTs.

\section{References}

1. Stewart RD: Endotracheal intubation. Current Therapy Emerg Med 1987;11-21.

2. American Heart Association: Instructor's Manual for Advanced Cardiac Life Support. 2d ed. Dallas, Tex:AHA, 1989.

3. Dauphinee K: Orotracheal Intubation. Emergency Medicine Clinics of North America; Airway management and anesthesia in the emergency department, 1988;6:699-713.

4. Iserson KV, Sanders AB, Kaback K: Difficult intubations: Aids and alternatives. Am Family Phys 1985;31:99-112.

Northern Illinois University, Dekalb, Illinois, USA 


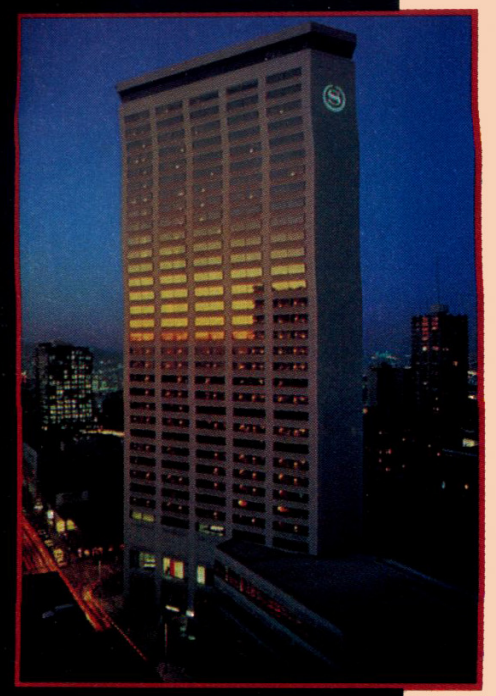

Come to Seattle for an advance look at The Future of Emergency Cardiac Care In early 1992, new standards for emergency cardiac care will be established... Will you be ready?

The Seventh Biennial International Educational Conference

\title{
Emergency Cardiac Care Update April 9-12, 1992
}

\author{
SEATTLE SHERATON HOTEL \& TOWERS • SEATTLE, WASHINGTON
}

Presented by the Citizen CPR Foundation, Inc. in conjunction with The Conference Corporation

If you are concerned about the future of Emergency Cardiac Care, plan to attend ECCU '92.

In early 1992, the American Heart Association will meet for the first time in seven years to discuss the major topics and changes in cardiac care.

At ECCU '92, key speakers and presenters will review the substance of the AHA meeting and provide a preview of changes to come

FACULTY INCLUDES:

Mickey Eisenberg, MD

Leonard Cobb, MD

Richard O. Cummins, MD

John Paraskos, MD

Joseph P. Ornato, MD

Timothy Crimmins, MD

Richard Kerber, MD

- Ventilation Discussions will include rate and duration of ventilation in non-intubated patients, use of adjuncts and sequencing of ventilation with chest compression.

Ethical-legal Topics The ethical-legal aspects of DNR orders, discontinuation of CPR and other efforts in the field, physician/family education including when to call 9-1-1, and an EMS approach to the DNR patient.

Acid-base Therapy Subjects will include timing and indication for sodium bicarbonate and alternative acid-base therapies.

Alpha Agents Learn about the best pressor agents and alpha agents in cardiac arrest and their most appropriate dose and timing.

- Early Access Discussions will include patient awareness of signs and symptoms of MI, appropriate response to "call fast, call 9-1-1," response of untrained people to a collapse, and sequencing of CPR for the sudden collapse vs. the unwitnessed or slow "collapse."

- Education What are the best approaches to teaching the adult learner? Is CPR training effective? Does it increase the chances that citizens will begin CPR?

ECCU ' 92 will provide a dynamic forum for individuals interested in developing, improving and expanding public and professional education in emergency cardiac care.

\section{Education in the Heart of Seattle}

For additional information, complete the coupon below and mail to

The Conference Corporation • P.O. Box 2400 • Carlsbad, CA 92018-2400 $619 / 431-8088$

Emergency Cardiac Care Update 1992

APRIL 9-12, 1992 • SEATTLE, WASHINGTON

Yes! Please put me on your mailing list to receive a conference brochure (to be mailed 11/91)

Name Title

Company Phone

Address

City

State Zip 


\section{Subscription and Business Information for the Readers of \\ Prehospital and Disaster Medicine}

\section{SUBSCRIPTION PRICES}

One-year

(4 issues)

Two-year

(8 issues)

Institutional $\ldots \ldots \ldots \ldots \ldots \ldots \ldots \ldots \ldots 78 \ldots \ldots \ldots \ldots 148$

Individual $\ldots \ldots \ldots \ldots \ldots \ldots \ldots \ldots \ldots \$ 48 \ldots \ldots$

Resident/In Training . . . . . . . .\$35 . . . . .\$65

EMT/Paramedic/Nurse . . . . . . \$35 . . . . .\$65

Note: "Institutional Subscribers" are defined as multiple reader subscribers and include public and private libraries, schools, hospitals and clinics; city, county, state, provincial and national government bureaus and departments; and all commercial and private institutions and organizations.

Individual subscriptions and all student-rate subscriptions must be in the name of, billed to, and paid by individuals. All studentrate requests must indicate training status and name of institution.

Send U.S. subscription orders to: Jems Publishing Company, PDM, P.O. Box 2789, Carlsbad, CA 92018; 619/431-9797; FAX: 619/431-8176.

\section{INTERNATIONAL SUBSCRIPTIONS}

International subscription orders should be directed to : Jems Publishing Company, P.O. Box 2789, Carlsbad, CA 92018; telephone: 619/431-9797; FAX: 619/431-8176. Canadian subscribers add $\$ 10$ per year for postage and handling. Please include payment in U.S. funds. All other international subscribers add $\$ 20$ per year.

\section{CHANGE OF ADDRESS \& MISSING ISSUES}

Please let your subscription representative know as soon as possible when you plan to move. We need four to six weeks advance notice for uninterrupted service. Send us your 1) current mailing label (with old address), 2) your new address and 3) effective date of change. If you did not receive an issue, let us know within three months of cover date.

If you have other questions about your subscription, please address them to: Customer Service, Jems Publishing Company, P.O. Box 2789, Carlsbad, CA 92018.

\section{EDITORIAL INFORMATION}

Please address all manuscript and editorial inquiries and comments to: Marvin L. Birnbaum, Editor, Prehospital and Disaster Medicine, 1552 University Ave., Rm. 434, Madison, WI 53705; 608/263-2069 or 608/263-7094; FAX: 608/263-2069.

\section{ASSOCIATION CONTACTS}

National Association of Emergency Medical Services Physicians, Executive and National Resource Center, 230 McKee Place, Suite 500, Pittsburgh, PA 15213; 1-800/228-3677.

World Association for Emergency and Disaster Medicine, Dr. Peter J.F. Baskett, President, Dept. of Anaesthesia, Frenchay Hospital, Bristol BS 16 1LE, United Kingdom.

Acute Care Foundation, P.O. Box 90193, Lakeland, FL, 33804 0193; 813/539-7352.

National Association for State EMS Directors, 1947 Camino Vida Roble, Suite 202, Carlsbad, CA 92008; 619/431-7054.

\section{Missing back issues of PDM? \\ Complete your \\ Prehospital and Emergency Medicine Journal Library}

Receive a FREE Listing of past issues simply by completing this form and mailing to: Jems Communications, P.O. Box 2789 Carlsbad, CA 92018

Yes, please send me a contents listing of all past issues of Prehospital and Disaster Medicine, and the Journal of the World Association for Emergency and Disaster Medicine.

Name (please print)

Organization

Address

City State Zip Phone ( ) 


\section{PREHOSPITAL and DISASTER MEDICINE}

\author{
A quarterly \\ peer-reviewed \\ scientific journal \\ for physicians, \\ nurses, paramedics, \\ instructors, \\ administrators \\ and researchers
}

\section{The official journal of: The National Association of EMS Physicians}

The World Association for Emergency and Disaster Medicine

\section{In Association with the} Acute Care Foundation and the National Association of State EMS Directors

\section{EMS INSIDER}

The EMS Insider is the monthly newsletter that provides the latest-breaking news about EMS legislation, regulations, medical developments and funding. It keeps EMS

decision makers abreast of the latest developments,

innovations and controversies in prehospital care.

Get EMS news while it's still NEW!

Subscribe today and save.

12 issues regularly $\$ 19.00$

SPECIAL INTRODUCTORY OFFER ..... . $\$ 29,50$

1 year (4 issues): $\square$ \$78 Institutional $\square$ \$48 Individual $\square$ \$35 Resident/In Training $\square$ \$35 EMT, Paramedic, RN 2 years (8 issues): $\square$ \$148 Institutional $\square$ \$88 Individual $\square$ \$65 Resident/In Training $\square$ \$65 EMT, Paramedic, RN NOTE: "Institutional" defines multiple reader subscriptions, including libraries, hospitals, government agencies, and all private organizations Individual subscriptions must be paid by individuals. This offer expires 03/31/92

Name/Institution

Address

City State ${ }^{\star}$

Zip

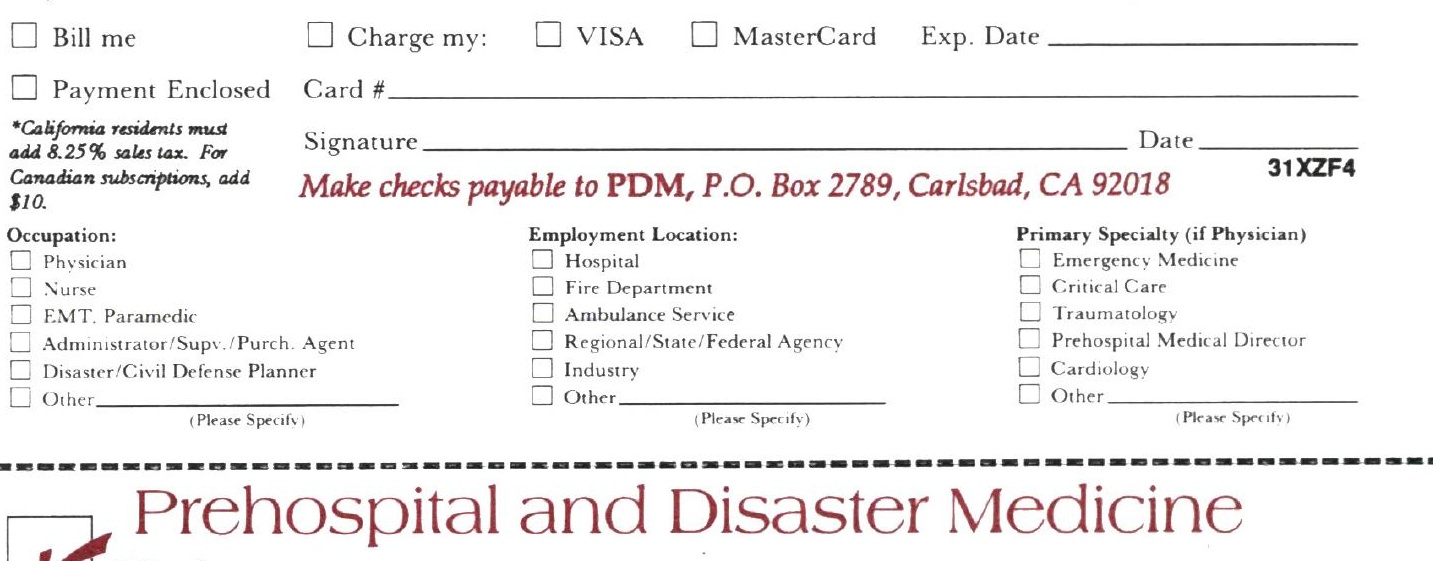
Yes! Please enter my subscription to PDM for:

1 year (4 issues): $\square$ \$78 Institutional $\square$ \$48 Individual $\square$ \$35 Resident/In Training $\square$ \$35 EMT, Paramedic, RN 2 years (8 issues): $\square$ \$148 Institutional $\square$ \$88 Individual $\square$ \$65 Resident/In Training $\square$ \$65 EMT, Paramedic, RN

NOTE: "Institutional" defines multiple reader subscriptions, including libraries, hospitals, government agencies, and all private organizations. Individual subscriptions must be paid by individuals.

Name/Institution

Address

Cit State*

Zip

$\begin{array}{ll}\square \text { Bill me } & \square \text { Charge my: } \square \text { VISA } \square \text { MasterCard Exp. Date } \\ \square \text { Payment Enclosed } & \text { Card \# }\end{array}$

* Califormia residents must add $8.25 \%$ sales tax. For Canadian subscriptions, add Make checks payable to PDM, P.O. Box 2789, Carlsbad, CA 92018

$31 \times Z F 4$

Occupation:

$\square$ Physician

Nurse

EMT, Paramedic

Administrator/Supv./Purch. Agent

$\square$ Disaster/Civil Defense Planner

$\square$ Other

(Please Specify)

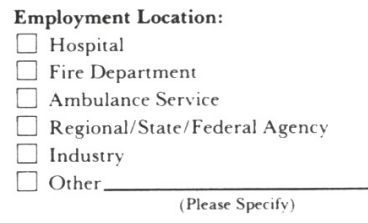

Employment Location:

$\square$ Fire Department

Ambulance Service

$\square$ Industry

(Please Specify)
Date

Primary Specialty (if Physician)

$\square$ Emergency Medicine

$\square$ Critical Care

$\square$ Traumatology

$\square$ Prehospital Medical Director

$\square$ Cardiology

$\square$ Other
Yes, I need the kind of timely information that only the EMS INSIDER provides. And by ordering now I'll take advantage of the introductory price-just $\$ 29.50$ for 12 monthly issues. (Regular price is $\$ 49.00$ )

Print Name

Title

Organization

\section{Address}

City

State *

Zip

BILL ME

C PAYMENT ENCLOSED

EMPLOYER/AFFILIATION

D 1. Hospital

2. Private Ambulance

3. Fire Dept./Rescue Squad

4. Third Serv./Mun. Agenc

5. Industrial/Commerical

6. Othe
OCCUPATION/POSITION

A. Physician

B. Nurse/Inst./Coord.

C. Administrator/Supervisor

G D. Paramed./EMT-1/EMT-D

E. ENIT (Basic, Ist Resp.)

F. Other
Offer expires 03/31/92

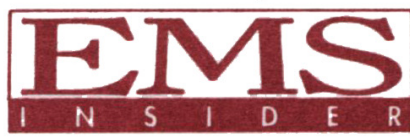

RISK FREE SUBSCRIPTION!

If you are unhappy with the EMS INSIDER, you may cancel your subscription at any time and receive a refund on the remaining issues.
CHARGE MY:

ت VISA MasterCard Exp. Date

Card \#

Signature

- California residents must add $8.25 \%$ sales tax: total is $\$ 31.93$. Canada-please add $\$ 6$ per year for postage. All other foreign-please add $\$ 10$ per year for surface mail postage; add $\$ 20$ per year for air mail postage. Please allow 6-8 weeks for delivery of first issue. 31 XZU6 


\section{BUSINESS REPLY MAIL \\ FIRST CLASS PERMIT NO.759 \\ CARLSBAD, CA}

POSTAGE WILL BE PAID BY ADDRESSEE

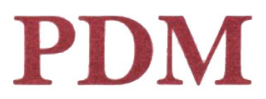

P.O. Box 2789

Carlsbad, CA 92018-9898

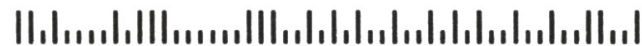

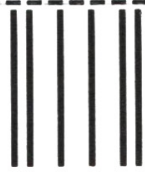

\section{BUSINESS REPLY MAIL \\ FIRST CLASS PERMIT NO.759 CARLSBAD, CA}

POSTAGE WILL BE PAID BY ADDRESSEE

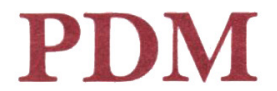

P.O. Box 2789

Carlsbad, CA 92018-9898

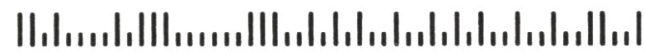

\section{BUSINESS REPLY MAIL \\ FIRST CLASS PERMIT NO.759 CARLSBAD, CA}

POSTAGE WILL BE PAID BY ADDRESSEE

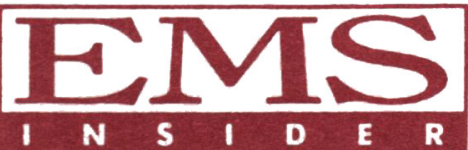

P.0. Box 2789

Carlsbad, CA 92018-9898

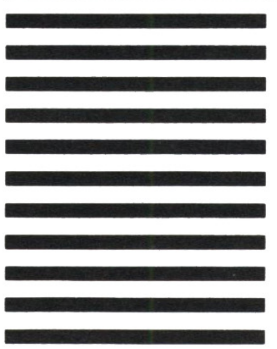

PDM

PREHOSPITAL and DISASTER MEDICINE

A quarterly

peer-reviewed scientific journal for physicians, nurses, paramedics, instructors, administrators and researchers

The official journal of: The National Association of EMS Physicians

The World Association for Emergency and Disaster Medicine

In Association with the Acute Care Foundation and the National Association of State EMS Directors

\section{EMS INSIDER}

The EMS Insider is the monthly newsletter that provides the latest-breaking news about EMS legislation, regulations, medical developments and

funding. It keeps EMS

decision makers abreast of the

latest developments,

innovations and controversies

in prehospital care.

Get EMS news while it's still

NEW!

Subscribe today and save.

12 issues regularly $\$ 49.00$

SPECIAL

INTRODUCTORY OFFER ...... \$29.50 


\section{Concise. Current. Reliable.}

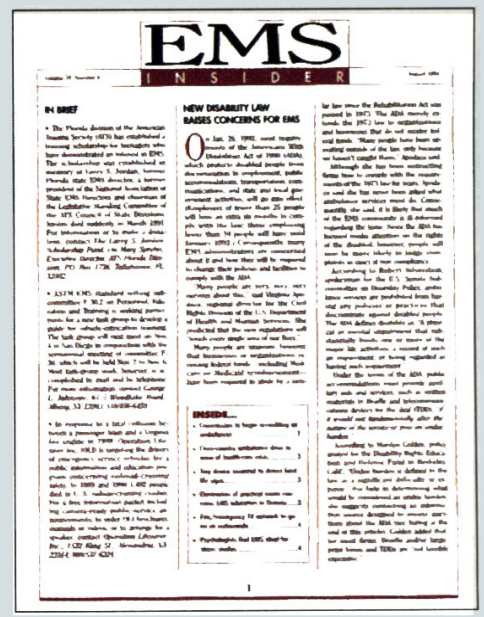

\section{The monthly must-have newsletter for emergency medical professionals}

Providing the industry's most up-to-date and incisive reporting on:

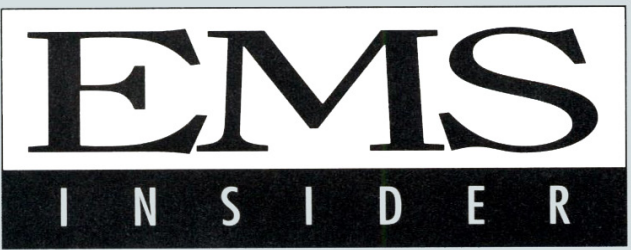

Published by Jems Communications
- Legislative issues-national,

state and local

- Grants and funding news

- New drugs and treatments

- Litigation

- New products

- Current controversies

The EMS INSIDER is your source for coverage of critical issues - issues that are evolving and dynamic, and that will dramatically affect the EMS industry. The staff of the EMS INSIDER reviews hundreds of reports and documents each month and interviews dozens of people to bring you the fastest-breaking news on a wide range of topics. We carefully check all information, and only print the most vital stories with the most immediate, universal use.

It's hard for busy managers to find time to read everything they'd like. The EMS INSIDER does it for you - then presents the information you need to keep up-to-date and informed.

You'll find articles about techniques that work like magic and innovations that went wrong. Read about legislation that can mean big benefits for ambulance services-and lawsuits that have put others out of business. When a controversy is brewing, we'll have a complete report. And as new drugs are successfully tested, we'll let you know when to expect to have access to them.

The information you get in the EMS INSIDER is often unavailable anywhere else. The stories we research so aggressively today are the stories that will shape EMS tomorrow. We think you deserve to know.

It's up to you. The news and issues of EMS are developing even as you read this.

Why wait? It's easy and inexpensive to get your own subscription started now. With the EMS INSIDER you'll get the best information as soon as it's available.

\section{To order, use the card beside this ad. Don't wait! If card is missing, call 1-800-266-JEMS. Outside the U.S. 619-431-9797.}


continued from page 491

5. Pons P: Esophageal obturator airway. Emergency Medicine Clinics of North America; Airway Management and Anesthesia in the Emergency Department 1988;6:693-697.

6. Safar P, Berkebile P, Scott MA, et al: Education research on lifesupporting first aid (LSFA) and CPR self-training systems (STS). Crit Care Med 1981;9:403-404.

7. Shea SR, MacDonald JR, Gruzinski G: Prehospital endotracheal tube airway or esophageal tube airway: A critical critique. Ann Emerg Med 1985;14:102-112.

8. MacLeod BA, Seaberg DC, Paris PM: Prehospital therapy, past, present and future. Emergency Medicine Clinics of North America; EMS/Prehospital Care, 1990;8:57-59.

9. Smith JR, Bodai BI, Auburg R, Ward RE: A field evaluation of the esophageal obturator airway. J Trauma 1983;23:313-321.

10. Smith JR, Bodai BI, Seifkin A, Palder S, Thomas V: The esophageal obturator airway: A review. JAMA 1983;250:1081-1084.

11. American Heart Associaton: Standards and Guidelines for Cardiopulmonary Resuscitation and Emergency Cardiac Care. JAMA 1986;255:2905-2937.

12. Danzl DF: Advanced Airway Support. In Emergency Medicine A Comprehensive Study Guide. Tintinalli JE, Rothstein RJ, Krome RL, eds. New York: McGraw Hill Book Company, 1985. pp 20-31.

13. Kastendick J: Airway Management. In Emergency Medicine: Concepts and Clinical Practice, Vol. One. Rosen P., et al, eds. St. Louis:C.V. Mosby Company, 1983. pp 26-53.

14. Deleo BC: Endotracheal intubation by rescue personnel. Heart Lung 1977;6:851-854.

15. Jacobs LM, Berrizbelitia LD, Bennett B, et al: Endotracheal intubation in the prehospital phase of emergency medical care. JAMA 1985;250:2175-2177.

16. Stewart RD, Paris PM, Pelton G, et al: Effect of varied training techniques on field endotracheal intubation success rates. Ann Emerg Med 1984;13:1032-1036.

17. Auerbach PS, Geehr EC: Inadequate oxygenation and ventilation using the esophageal gastric tube airway in the prehospital setting. JAMA 1983;250:3067-3071.

18. American Heart Association: Textbook of Advanced Cardiac Life Support ${ }_{2}$ Second Edition, 1987. pp 1-8.

19. White RD: Making EMT-D work: Proceedings from the University of Iowa workshop. JEMS, 1986;11:26-32.

20. Eisenberg MS, Hallstrom AP, Copass MK, et al: Treatment of outof-hospital cardiac arrests with rapid defibrillation by emergency medical technicians. N Engl J Med 1980;302:1379-1383.

21. Stults KR, Brown DD, Schug VL, Bean JA: Prehospital defibrillation performed by emergency medical technicians in rural communities. NEngl J Med 1984;310:219- 223. 


\section{You Can Make A Difference}

\section{Cervical Spine Issues in Prehospital Medicine}

An educational videotape by Ron Stewart, $M D$

Every year, 13,000 Americans suffer a spinal cord injury. Of those victims, 8,000 survive thanks to advances in the study of cervical spine issues.

Dr. Stewart examines the history of spinal cord injury (SCI) and presents some startling numbers on the changing face of SCI treatment in the prehospital setting. Learn the facts about SCI and how you can make a difference.

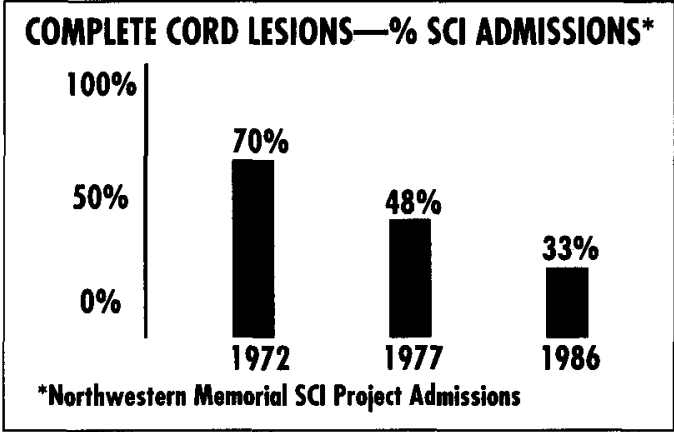

Spinal cord injury $(\mathrm{SCl})$ registries reveal a consistent decline in the number of patients with complete cord lesions presenting to hospitals caring for SCI. In 1972, some 70 percent of patients presenting to major SCI centers had complete cord lesions, compared to 48 percent in 1977 and 33 percent in 1986. Many would attribute much of this decline to improved training. procedures, and equipment of prehospital care personnel.

Cervical Spine Issues in Prehospital Medicine is a non-profit videotape produced by California Medical Products in conjunction with Emergency Medical Update. Proceeds from the sale of every tape go to support research conducted by the National Association of EMS Physicians.

\section{Cervical Spine Issues in Prehospital Medicine: $\$ 49.95$}

MAIL TO: The Jems Bookstore • P.O. Box 2789 - Carlsbad, CA 92018

YeS. I'd like to order Cervical Spine Issues in Prehospital Medicine for $\$ 49.95$.

Name

Institution

Address

City/State/Zip

Charge My: $\square$ VISA $\square$ MasterCard

ACCOUNT NUMBER

EXPIRATION DATE

SIGNATURE

(Please add $\$ 3.00$ shipping and handling.)

PDM 10/91
Mail to: The Jems Bookstore

P.O. Box 2789

Carlsbad, CA 92018

You may order by calling the Jems Bookstore, toll-free, at

1-800-266-JEMS

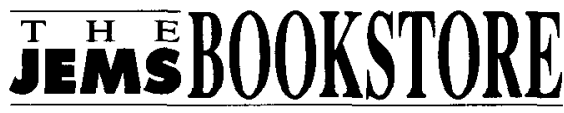



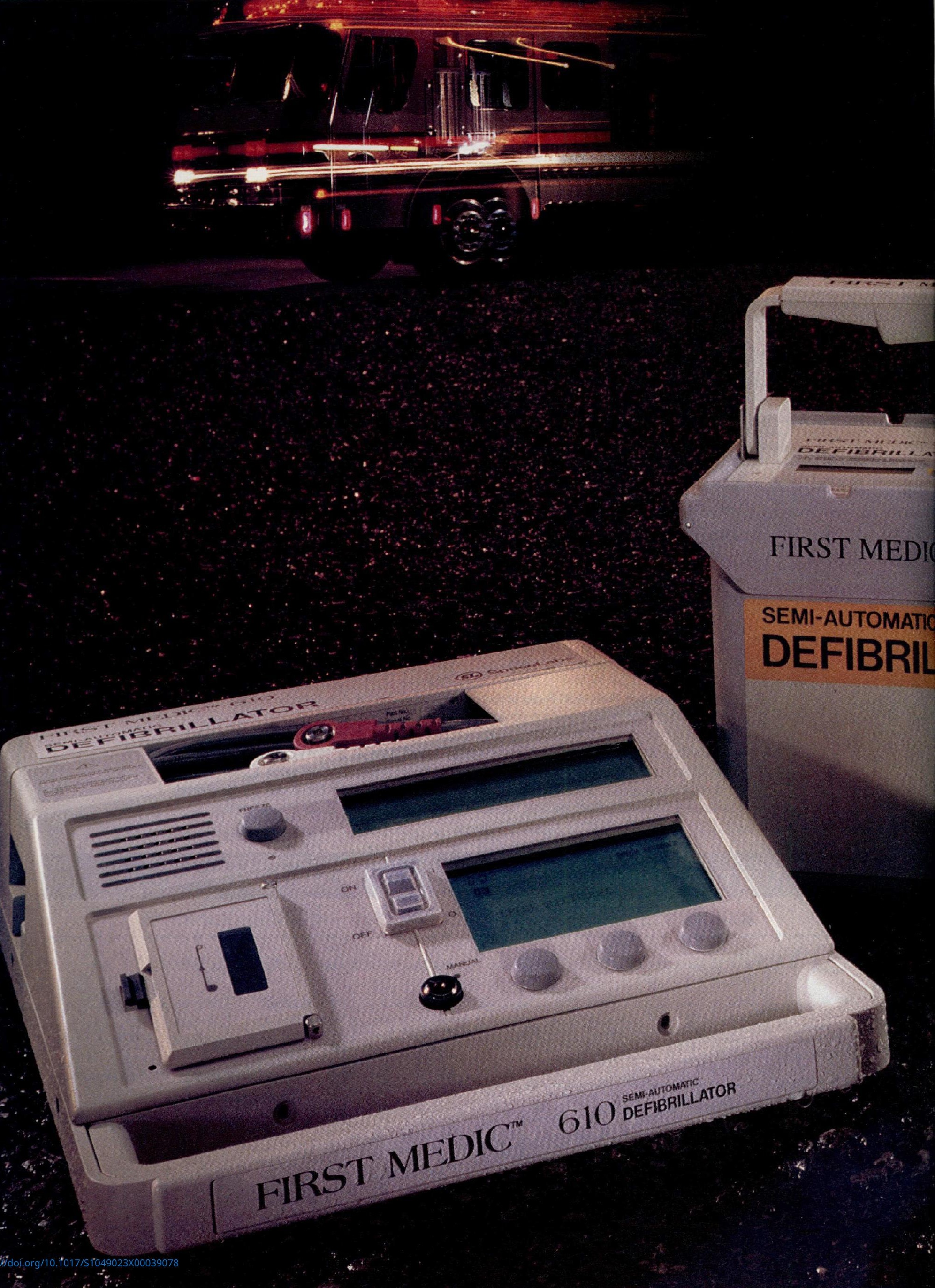

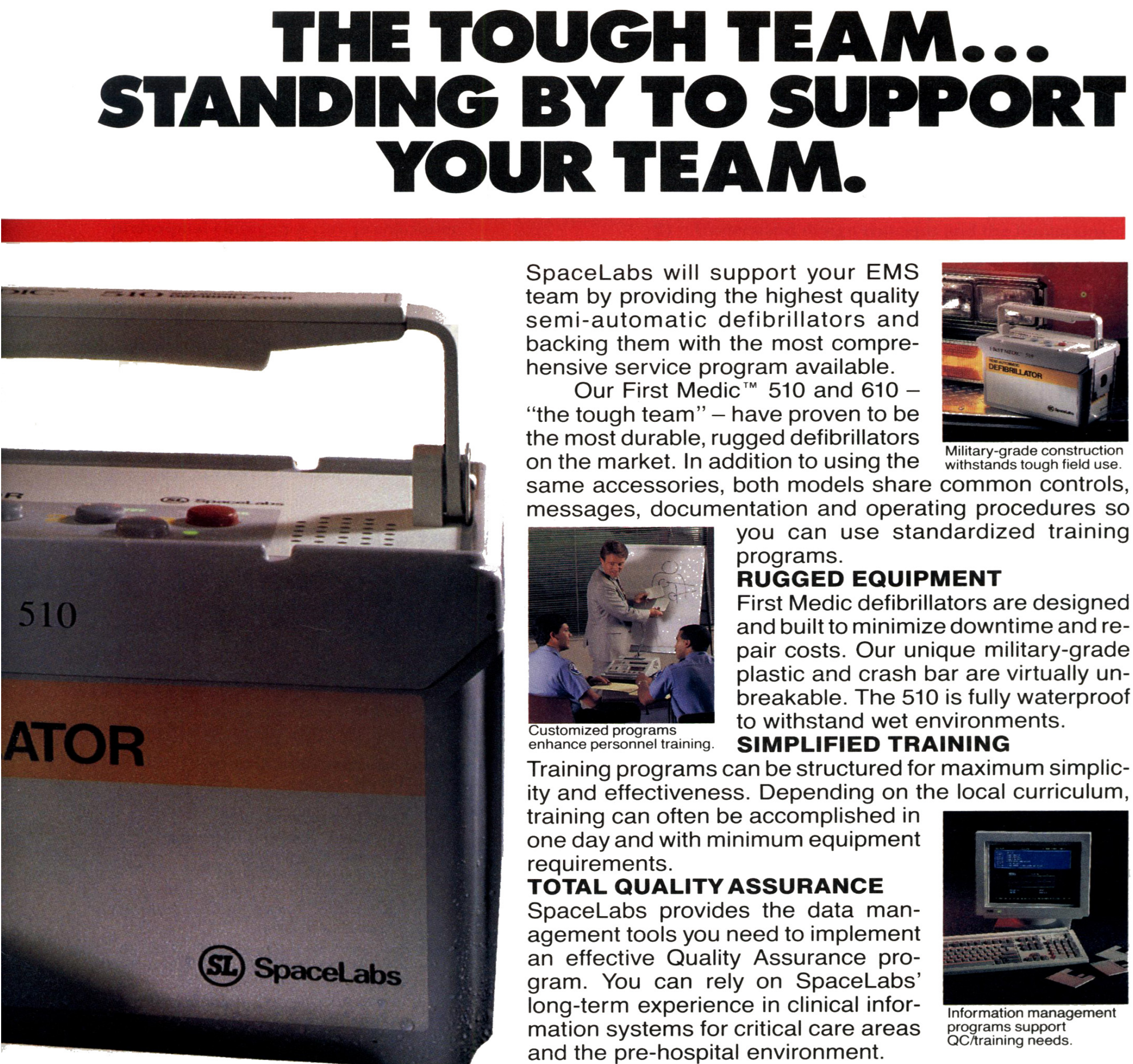

SpaceLabs will support your EMS team by providing the highest quality semi-automatic defibrillators and backing them with the most comprehensive service program available.

Our First Medic ${ }^{\mathrm{TM}} 510$ and 610 "the tough team" - have proven to be the most durable, rugged defibrillators on the market. In addition to using the

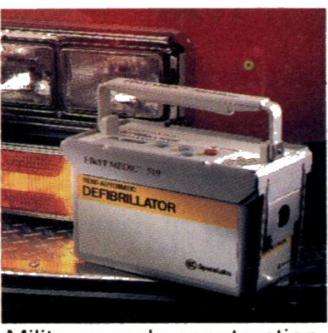

Military-grade construction withstands tough field use. same accessories, both models share common controls, messages, documentation and operating procedures so

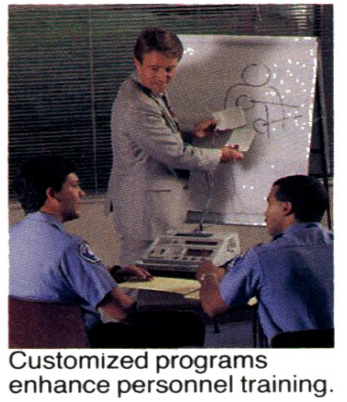
you can use standardized training programs.

\section{RUGGED EQUIPMENT}

First Medic defibrillators are designed and built to minimize downtime and repair costs. Our unique military-grade plastic and crash bar are virtually unbreakable. The 510 is fully waterproof to withstand wet environments.

\section{SIMPLIFIED TRAINING}

Training programs can be structured for maximum simplicity and effectiveness. Depending on the local curriculum, training can often be accomplished in one day and with minimum equipment requirements.

\section{TOTAL QUALITY ASSURANCE}

Spacelabs provides the data management tools you need to implement an effective Quality Assurance program. You can rely on SpaceLabs' long-term experience in clinical information systems for critical care areas and the pre-hospital environment.

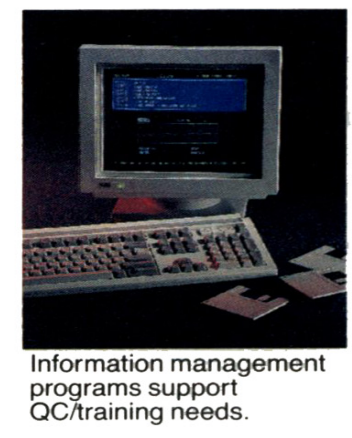

\section{COMPREHENSIVE CUSTOMER SERVICE}

SpaceLabs supports the pre-hospital emergency market

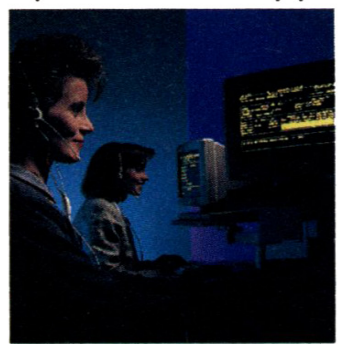

Service support available 24 hours a day. with a customer service team of over 300 worldwide. With our First-Call ${ }^{\mathrm{TM}}$ centralized service system you get the immediate response and service you require . . .24 hours a day, seven days a week. Find out more about how our team supports your team: call 1-800251-9910.

\section{SL) Spacelabs}

The Clinical Information Company 